\title{
Development and validation of UV spectrophotometric method for orbifloxacin assay and dissolution studies
}

\author{
Edith Cristina Laignier Cazedey, Hérida Regina Nunes Salgado*
}

School of Pharmaceutical Sciences, State University of São Paulo “Júlio de Mesquita Filho”, Araraquara, São Paulo, Brazil

\begin{abstract}
New, simple and cost effective UV-spectrophotometric method was developed for the estimation of orbifloxacin in pharmaceutical formulation. Orbifloxacin was estimated at $290 \mathrm{~nm}$ in $0.5 \mathrm{M}$ hydrochloric acid. Linearity range was found to be $1.0-6.0 \mu \mathrm{g} \mathrm{mL} \mathrm{m}^{-1}$. The method was tested and validated for various parameters according to main guidelines. The proposed method was successfully applied for the determination of orbifloxacin in tablets. The results demonstrated that the procedure is accurate, precise and reproducible, while being simple, economical and less time consuming. It can be suitably applied for the estimation of orbifloxacin in routine quality control and dissolution studies.
\end{abstract}

Uniterms: Medicines/quality control. Medicines/dissolution. Orbifloxacin/determination. UV spectrophotometry/quantitative analysis/validation.

\begin{abstract}
Um método espectrofotométrico novo, simples e de baixo custo foi desenvolvido para a determinação de orbifloxacino em formulação farmacêutica. O orbifloxacino foi determinado em $290 \mathrm{~nm}$ utilizando ácido clorídrico 0,5 M como solvente. $\mathrm{O}$ intervalo de linearidade usado foi de 1,0 a $6,0 \mu \mathrm{g} \mathrm{mL} \mathrm{mL}^{-1}$. O método foi testado e validado em vários parâmetros de acordo com os principais guias. O método proposto foi aplicado com sucesso para a determinação de orbifloxacino em comprimidos. Os resultados demonstraram que este procedimento é exato, preciso e reprodutível, ao mesmo tempo em que é simples, barato e de mais rápida execução e pode ser adequadamente aplicado para a determinação de orbifloxacino na rotina do controle de qualidade e em estudos de dissolução de comprimidos contendo este fármaco.
\end{abstract}

Unitermos: Medicamentos/controle de qualidade. Medicamentos/dissolução. Método analítico. Orbifloxacino/determinação. Espectrofotometria na região do UV/controle de qualidade/validação.

\section{INTRODUCTION}

The fluoroquinolones are a class of compounds that comprise a large and expanding group of synthetic antimicrobial agents. Orbifloxacin (Figure 1, CAS: 113617-63-3), namely 1-cyclopropyl-5,6,8-trifluoro1,4-dihydro-7-(cis-3,5-dimethyl-1-piperazinyl)-4oxoquinoline-3-carboxylic acid, is a new third-generation fluoroquinolone antibacterial drug, developed mainly for the treatment of gastrointestinal and respiratory infections in animals (Nakamura, 1995; Matsumoto et al., 1999a,b; Martinez, McDermott, Walker, 2006). It is also used for the treatment of skin, soft tissue and urinary tract infections

\footnotetext{
*Correspondence: H. R. N. Salgado. Faculdade de Ciências Farmacêuticas, Universidade Estadual de São Paulo "Júlio de Mesquita Filho". Rodovia Araraquara-Jaú, km 1, 14801-902 - Araraquara - SP, Brasil. E-mail: salgadoh@fcfar.unesp.br
}

particularly in dogs and cats (Davis, Papich, Weingarten, 2006; Marín et al., 2008). Recent studies have shown that orbifloxacin is effective in the treatment of staphylococcal pyoderma superficial and deep infections (Scott, Peters, Miller Jr, 2006); active against Pseudomonas aeruginosa isolated from canine otitis (Mckay et al., 2007), and Staphylococcus intermedius responsible for canine skin and ear infections (Ganière, Médaille, Etoré, 2004). Further, research was also being conducted on widening the antibacterial spectrum of orbifloxacin and using it for treatment of infection of other animals, such as horses and rabbits (Davis, Papich, Weingarten, 2006; Marín et al., 2008; Haines et al., 2001).

Fluoroquinolones have become an important group, particularly for the treatment of infections caused by more conventional antibiotic-resistant bacteria (Haines et al., 2001). Antimicrobial resistance in bacteria is a 


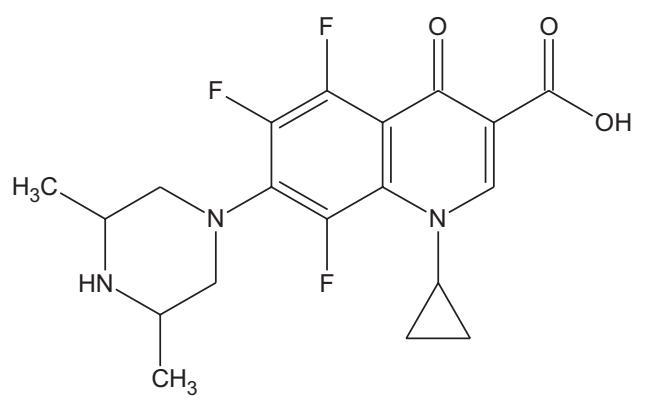

FIGURE 1 - Chemical structure of orbifloxacin.

phenomenon that has been in constant evolution since the introduction of antibiotics. Several factors are known to promote bacterial resistance, including poor compliance with treatment regimen (DiPersio et al., 1998; Grave, Tanem, 1999), prophylactic use of antibiotics (Rantala et al., 2004), and the use of antibiotics as growth promoters (Boerlin et al., 2001; Emborg et al., 2004) emphasizing the importance dosages and treatment appropriate.

For an appropriate dosage of the pharmaceutical form orbifloxacin analytical methods should be developed and validated. To date, methods described in the scientific literature for determination of this analyte in biological and other samples involve liquid chromatography with UV (Matsumoto et al., 1999a,b; Davis, Papich, Weingarten, 2006; Morimura et al., 1995a; Morimura et al., 1995b; Morimura, Nobuhara, Matsukura, 1997; Morimura et al., 1997; Matsumoto et al., 1998a; Matsumoto et al., 1998b; Matsumoto et al., 1999a,b; Hung et al., 2007; British Pharmacopoeia, 2011; Cazedey et al., 2011; United States Pharmacopeia 34, 2011; Yu et al., 2012), fluorimetry (Marín et al., 2008; Hung et al., 2007; García et al., 1999; Kay-Mugford et al., 2002; Schneider, Donoghue, 2002; Schneider, Donoghue, 2003; Schneider et al., 2005; Schneider, Reyes-Herrera, Donoghue, 2007; Marín et al., 2007; Chonan et al., 2008; Abd ElAty et al., 2009; Elias et al., 2009; Gebru et al., 2009; Cho et al., 2010) and/or detection by mass spectrometry (Matsumoto et al., 1999a,b; Morimura, Nobuhara, Matsukura, 1997a; Morimura et al., 1997; Matsumoto et al., 1998a; Matsumoto et al., 1998b; Matsumoto et al., 1999a,b; Yu et al., 2012; Schneider, Donoghue, 2002; Schneider, Donoghue, 2003; Schneider et al., 2005; Schneider, Reyes-Herrara, Donoghue, 2007; Johnston, Mackay, Croft, 2002; Yamada et al., 2006; Fujita et al., 2008; Kajita, Hatakeyama, 2008; Saito et al., 2008; Li et al., 2009; Santoke et al., 2009; Kantiani, Farré, Barcelo, 2011; Tang et al., 2012).

Other techniques include the determination of orbifloxacin by sequence analysis of samples sensitized with luminescent terbium (Llorent-Martínez et al., 2008) and by microbiological method (Cazedey, Salgado, 2011).

Also, other ultraviolet analyses have been described for fluoroquinolones, such as sparfloxacin (Marona, Schapoval, 1999), lomefloxacin (Gomes, Salgado, 2005) and gatifloxacin (Salgado, Oliveira, 2005).

The objective of the present study was to develop a simple, precise, accurate and economical analytical method with the better detection range for estimation of orbifloxacin in pharmaceutical formulations and dissolution studies.

\section{MATERIAL AND METHODS}

\section{Material and reagents}

Orbifloxacin reference standard (assigned purity $99.8 \%$ ) was supplied by Sigma-Aldrich. The pharmaceutical form tablets were commercially obtained and claimed to contain $22.7 \mathrm{mg}$ orbifloxacin (Orbax ${ }^{\mathrm{TM}}$ Schering-Plough). All reagents used were analytical grade.

\section{Apparatus}

A Shimadzu UV-Vis spectrophotometer, model UVmini-1240 was used. UV spectra absorbance of reference and sample solutions were recorded in $10 \mathrm{~mm}$ quartz cells at $290 \mathrm{~nm}$. The solutions were prepared in $0.5 \mathrm{M}$ hydrochloric acid.

\section{Methods}

\section{Analytical method development}

Different media were investigated to develop a suitable UV-spectrophotometric method for the analysis of orbifloxacin in tablets. For selection of media the criteria employed were sensitivity of the method, ease of sample preparation, solubility of the drug, cost of solvents and the applicability of the method to various purposes.

\section{Preparation of standard solutions}

The orbifloxacin reference standard solution (100.0 $\left.\mu \mathrm{g} \mathrm{mL}^{-1}\right)$ was prepared by accurately weighing $5.0 \mathrm{mg}$ of orbifloxacin reference in a $50.0 \mathrm{~mL}$ volumetric flask. The volume was completed with $0.5 \mathrm{M}$ hydrochloric acid. This flask was sonicated for $30 \mathrm{~min}$. The above solution was diluted in a $10 \mathrm{~mL}$ volumetric flask with $0.5 \mathrm{M}$ hydrochloric acid to obtain a final solution containing $3.5 \mu \mathrm{g} \mathrm{mL}^{-1}$ of orbifloxacin.

\section{Determination of maximum absorption $\left(\lambda_{\max }\right)$}

From the standard solution $\left(100.0 \mu \mathrm{g} \mathrm{mL}^{-1}\right)$ 
approximately $3.0 \mathrm{~mL}$ was taken and scanned from 200 to $400 \mathrm{~nm}$ with the UV spectrophotometer. The $0.5 \mathrm{M}$ hydrochloric acid was used as blank. Orbifloxacin presented maximum absorption at $290 \mathrm{~nm}$.

\section{Calibration curve}

The calibration curve was constructed by analyzing six different concentrations of standard solution, prepared on the same day. The range of solutions varied from 1.0 to $6.0 \mu \mathrm{g} \mathrm{mL} \mathrm{mL}^{-1}$. All determinations were conducted in triplicate.

Assay

To analyze the concentration of orbifloxacin tablets, 20 tablets were individually weighed and triturated to obtain homogeneous mixture. An amount of powder equivalent to $5.0 \mathrm{mg}$ of drug was transferred to $50.0 \mathrm{~mL}$ volumetric flask. The volume was completed with $0.5 \mathrm{M}$ hydrochloric acid. The resulting solution was sonicated for $30 \mathrm{~min}$ to ensure proper solubilization. Aliquots of this solution were further diluted with the same solvent, in order to obtain a solution with final concentration of $3.5 \mu \mathrm{g} \mathrm{mL}^{-1}$. All sample solutions were filtered through a quantitative filter. All determinations were conducted in triplicate.

\section{Chromatographic conditions}

In order to compare the results of the proposed UV spectrophotometric method with a reference method, the same product batches were analyzed by an HPLC technique, which was developed and validated by our research group (Cazedey et al., 2011). The mobile phase consisted of 5\% acetic acid: methanol $(80: 20, \mathrm{v} / \mathrm{v})$. A flow

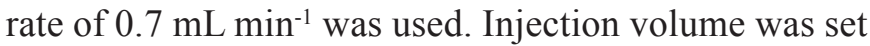
at $20 \mu \mathrm{L}$. UV detection of the analyte was carried out at $290 \mathrm{~nm}$.

\section{Dissolution studies}

A dissolution test for evaluation of the dissolution behavior of orbifloxacin tablets was also developed and the profiles were generated. Dissolution samples were analyzed with both HPLC (Cazedey et al., 2011) and the developed UV spectrophotometric method with UV detection at $290 \mathrm{~nm}$. Dissolution studies were carried out in USP dissolution apparatus 2 using $0.05 \mathrm{M}$ phosphate buffer ( $\mathrm{pH}$ 6.8) as dissolution medium. The dissolution medium was found suitable to ensure sink conditions and chemical stability of orbifloxacin. The rotation speed was kept at $50 \mathrm{rpm}$ and the volume of the dissolution medium was $900 \mathrm{~mL}$. In both methods, the samples were diluted with $0.5 \mathrm{M}$ hydrochloride acid to a final concentration of
$2.5 \mu \mathrm{g} \mathrm{mL}^{-1}$. The results from $60 \mathrm{~min}$, the last time point of the dissolution tests performed, were consistent with the Assay results.

\section{Analytical Validation}

\section{Selectivity}

One of the several ways to assess selectivity is a comparison between a matrix without analyte and a matrix with the analyte added. In this case, the excipients comprising the matrix should not interfere with the assay result (ICH, 2005). However, if a matrix without the analyte is not available, the selectivity determination can be carried out by comparing the slope of two standard analytical curves. One curve includes the sample matrix, and the other represents a sample without matrix. The selectivity is then assessed by comparing these two linear regression curve slopes. If they are similar, the method is considered selective and the matrix did not cause interference in the method (Bonfilio et al., 2012). Thus, orbifloxacin standard and sample solutions (1.0 to $6.0 \mu \mathrm{g} \mathrm{mL}^{-1}$ ) were prepared in the selected medium and the analytical curves were statistically compared. Additionally, the Student's $t$-test and $F$-test were performed to compare the orbifloxacin standard and sample absorption values.

Linearity

To establish linearity of the proposed method, six series of orbifloxacin standard solution $\left(1.0-6.0 \mu \mathrm{g} \mathrm{mL}^{-1}\right)$ were prepared from the stock solutions and analysed on three consecutive days. Least square regression analyses were done for the obtained data. ANOVA test (one-way) was performed based on the absorbance values observed for each pure drug concentration during the replicate measurement of the standard solutions.

\section{Precision}

Precision was determined by using data from the intraday and interday repeatability studies. Same level of drug concentration $\left(3.5 \mu \mathrm{g} \mathrm{mL}^{-1}\right)$, prepared from independent stock solution was used for both the studies. The solutions of orbifloxacin in six replicates were prepared at two different times in a day and studied for intraday variation. Same protocol was followed for three different days to study interday variation $(n=18)$. The method precision was evaluated by calculating relative standard deviation (RSD\%).

\section{Accuracy}

To determine the accuracy of the proposed method, standard addition method was performed. In this study, 
different concentrations of pure drug $(0.8,1.5$ and $2.2 \mu \mathrm{g} \mathrm{mL}^{-1}$ ) were added to a known quantity of sample and the total concentration was determined using the proposed methods $(n=9)$. The percent recovery $(\% R)$ of the added pure drug was calculated as shown in equation 1(AOAC, 2002):

$$
\% R=\left[\left(\frac{C_{t}-C_{u}}{C_{a}}\right)\right] \times 100
$$

where $C_{t}$ is the total drug concentration measured after standard addition; $C_{u}$ represents the drug concentration in the formulation; and $\mathrm{Ca}$, the drug concentration added to formulation.

\section{Limit of detection and limit of quantitation}

The limit of detection (LOD) and limit of quantitation (LOQ) of orbifloxacin by the proposed methods were determined using analytical curves. LOD and LOQ were calculated as shown in equations 2 and 3 respectively (ICH, 2005):

$$
\begin{aligned}
& L O D=\frac{3.3 \sigma}{S} \\
& L O Q=\frac{10 \sigma}{S}
\end{aligned}
$$

where $\sigma$ is the standard deviation of y-intercept of regression equation and $\mathrm{S}$ is the slope of the calibration curve.

\section{Robustness}

Robustness of the proposed method was determined by changing wavelength from $290 \mathrm{~nm}$ to 289 and $291 \mathrm{~nm}$. The same concentration $\left(3.5 \mu \mathrm{g} \mathrm{mL}^{-1}\right)$ was prepared in six replicates for each wavelength. The Student's $t$ tests were performed and $t$-values were determined.

\section{RESULTS AND DISCUSSION}

Different media were investigated to develop a suitable UV spectrophotometric method for the analysis of orbifloxacin in formulation. The solvents tested are the following: water, ethanol, ethanol:water (50:50, $\mathrm{v} / \mathrm{v})$, methanol, $0.1 \mathrm{M}$ hydrochloric acid $(\mathrm{HCl}), 0.5 \mathrm{M}$ hydrochloric acid and $1 \mathrm{M}$ sodium hydroxide aqueous $(\mathrm{NaOH})$. All the solutions were sonicated for 30 minutes (Table I). These solvents were tested with respect to the extraction efficiency. The best solvent to extract orbifloxacin was $0.5 M$ hydrochloric acid with extraction efficiency of $102 \%$.
TABLE I - Extraction rate of orbifloxacin from the pharmaceutical dosage form

\begin{tabular}{lc}
\hline Solvent & \% extracted orbifloxacin* \\
\hline Water & $\approx 78$ \\
Ethanol & $\approx 68$ \\
Ethanol: water $(50: 50, \mathrm{v} / \mathrm{v})$ & $\approx 87$ \\
Methanol & $\approx 89$ \\
$0.1 \mathrm{M} \mathrm{HCl}$ & $\approx 90$ \\
$0.5 \mathrm{M} \mathrm{HCl}$ & $\approx 102$ \\
$0.1 \mathrm{M} \mathrm{NaOH}$ & $\approx 12$ \\
\hline
\end{tabular}

*All solutions were sonicated for 30 minutes

For media optimization various solvents like water, methanol, $0.1 \mathrm{M}$ sodium hydroxide, $5 \%$ acetic acid (HOAc) and $0.5 \mathrm{M}$ hydrochloric acid were investigated. Orbifloxacin showed $\mathrm{pH}$ dependent UV absorption spectra (Table II). This implies that the $\mathrm{pH}$ of the analytical medium is very important for estimation of orbifloxacin. Orbifloxacin UV absorption spectra in alkali medium showed various other bands that could be due to degradation of the drug. The final decision of using 0.5 $\mathrm{M}$ hydrochloric acid as a media was based on criteria like residue generation, sensitivity of the method, cost, ease of sample preparation, solubility, and applicability of the method.

TABLE II - Wavelength and absorption of orbifloxacin $\left(10.0 \mu \mathrm{g} \mathrm{mL}^{-1}\right)$ in different solvents

\begin{tabular}{lcc}
\hline Solvent & $\begin{array}{c}\text { Wavelength }\left(\boldsymbol{\lambda}_{\max }\right) \\
(\mathbf{n m})\end{array}$ & Absorption \\
\hline Water & 290 & 0.9934 \\
Methanol & 291 & 1.0313 \\
$0.1 \mathrm{M} \mathrm{NaOH}$ & 288 & 1.4901 \\
$5 \% \mathrm{HOAc}$ & 290 & 1.1724 \\
$0.5 \mathrm{M} \mathrm{HCl}$ & 290 & 1.1888 \\
\hline
\end{tabular}

The $\lambda_{\max }$ of orbifloxacin in $0.5 \mathrm{M}$ hydrochloric acid was found to be $290 \mathrm{~nm}$. Apparent molar absorptivity $(\varepsilon)$ of drug, determined by using Beer's law, was found to be 4.33 $\times 10^{4} 1 \mathrm{~mol}^{-1} \mathrm{~cm}^{-1}$ (Table III), this value was calculated according to the standard formulae (Equation 4):

$$
\varepsilon=\frac{A}{c \times b}
$$

where $\mathrm{A}$ is the absorbance; $\mathrm{c}$, molar concentration $(\mathrm{mol} / \mathrm{L})$ and; $b$, the cell optical length $(\mathrm{cm})$.

In $0.5 \mathrm{M}$ hydrochloride acid, the linearity range 
TABLE III - Optical characteristics, statistical data of the regression equations and validation parameters for orbifloxacin

\begin{tabular}{|c|c|c|}
\hline Parameter & & \\
\hline Optical characteristics & & \\
\hline Apparent molar absorptivity $\left(\mathrm{L} \mathrm{mol}^{-1} \mathrm{~cm}^{-1}\right)$ & & $4.33 \times 10^{4}$ \\
\hline Regression analysis & & \\
\hline Slope (S.E. $\left.{ }^{a}\right)$ & & $0.1107(0.0006)$ \\
\hline Intercept (S.E. $\left.{ }^{a}\right)$ & & $-0.0028(0.0008)$ \\
\hline Regression coefficient $(r)$ & & 0.9999 \\
\hline Calculated $F$-value (critical $F$-value) ${ }^{\mathrm{b}}$ & & $2215.15(4.75)$ \\
\hline Validation Parameters & & \\
\hline Selectivity & $F_{\text {cal }}\left(F_{\text {crit }}\right)^{\mathrm{c}}$ & $0.86(5,05)$ \\
\hline & $t_{\mathrm{cal}}\left(t_{\mathrm{crit}}\right)^{\mathrm{c}}$ & $1.74(1.81)$ \\
\hline Linearity $\left(\mu \mathrm{g} \mathrm{mL} \mathrm{L}^{-1}\right)$ & & $1.0-6.0$ \\
\hline $\operatorname{LOD}\left(\mu \mathrm{g} \mathrm{mL}^{-1}\right)$ & & 0.04 \\
\hline $\mathrm{LOQ}(\mu \mathrm{g} \mathrm{mL}-1)$ & & 0.12 \\
\hline Accuracy - recovery (RSD\%) & & $99.77(1.78)$ \\
\hline Precision $\left(\mathrm{RSD}^{\mathrm{N}}\right)^{\mathrm{d}}$ & Intraday & 1.23 \\
\hline & Interday & 1.31 \\
\hline Robustness - $t_{\text {cal }}\left(t_{\text {crit }}\right)^{\mathrm{c}}$ & $290-289 \mathrm{~nm}$ & $1.61(2.18)$ \\
\hline & $290-291 \mathrm{~nm}$ & $0.36(2.18)$ \\
\hline
\end{tabular}

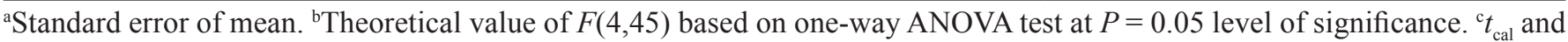
$F_{\text {cal }}$ are calculated values and $t_{\text {crit }}$ and $F_{\text {crit }}$ are theoretical values $(\mathrm{n}=6)$ based on paired Student's $t$-test and $F$-test, respectively, at $P=0.05$ level of significance. ${ }^{\mathrm{d}}$ Relative standard deviation

was found to be 1.0 to $6.0 \mu \mathrm{g} \mathrm{mL} \mathrm{m}^{-1}$. The linear regression equation obtained was: absorbance at $290 \mathrm{~nm}=[0.1107 \times$ concentration in $\mu \mathrm{g} \mathrm{mL}^{-1}$ ] -0.0028 ; with a regression coefficient of 0.9999 (Table III).

Absorption spectrum of pure drug sample was matching with the marketed formulation sample in the selected medium. The calculated Student's $t$-values and $F$-values were found to be less than that of the critical values, indicating that statistically there was no significant difference between mean absorbance of solutions prepared from pure drug sample and marketed formulation sample (Table III). Moreover, the analytical curves of orbifloxacin standard and sample solutions were compared and presented no significant statistical difference (Figure 2). Therefore, proposed method is considered selective for the orbifloxacin.

Accuracy ranged from $98.04 \%$ to $101.58 \%$. The excellent mean $\%$ recovery values (nearly $100 \%$ ) and its low relative standard deviation values $(\mathrm{RSD} \%<2.0)$ represent accuracy (Table III) of the UV spectrophotometric method.

Precision was determined by studying repeatability and intermediate precision. Repeatability results indicate

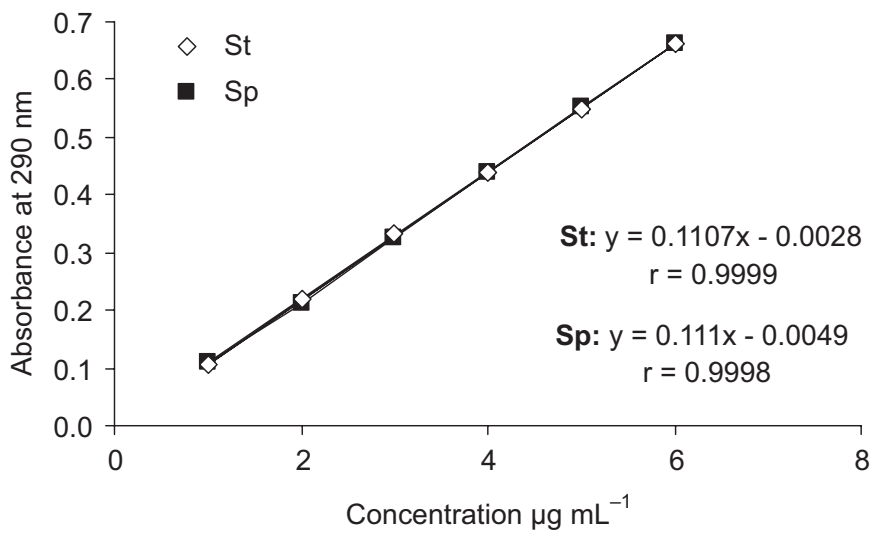

FIGURE 2 - Statistical comparison of orbifloxacin standard $(\mathrm{St})$ and sample $(\mathrm{Sp})$ analytical curves in the range of 1.0 to $6.0 \mu \mathrm{g} \mathrm{mL}^{-1}$.

the precision under the same operating conditions over a short interval of time and inter-assay precision (intraday). Intermediate precision expresses the results in different days (interday). The precision RSD\% values were not more than $1.5 \%$ in all the cases (Table III). RSD values were within the acceptable range indicating that this method has excellent repeatability and intermediate precision. 
TABLE IV - Comparison of the proposed UV spectrophotometric method and an HPLC method for the assay and dissolution test of orbifloxacin in tablets

\begin{tabular}{lcccc}
\hline Method & Mean \% drug related to label claim & RSD\% & Mean \% drug dissolved & RSD\% $^{\mathbf{b}}$ \\
\hline $\mathrm{UV}^{\mathrm{a}}$ & 100.74 & 0.66 & 96.84 & 3.14 \\
HPLC & 24 & 1.31 & 94.25 & 2.04 \\
\hline
\end{tabular}

${ }^{a}$ UV: UV spectrophotometric method. bin 60 minutes ( $n=6$ vessels)

LOD and LOQ, calculated according to the ICH (2005) guidelines, were found to be $0.04 \mu \mathrm{g} \mathrm{ml}^{-1}$ and 0.12 $\mu \mathrm{g} \mathrm{mL} \mathrm{L}^{-1}$, respectively.

Variation of wavelengths by $\pm 1 \mathrm{~nm}$ did not have any significant effect on absorbance (Table III). The Student's $t$-test values in both cases-variation were not statistically significant $\left(t_{\text {cal }}<t_{\text {crit }}\right)$, indicating that the developed method was robust.

The proposed analytical method was applied for determination of orbifloxacin in tablets. The assay values of orbifloxacin in tablets ranged from $99.99 \%$ to $101.25 \%$ with standard deviation not more than $0.66 \%$. The estimated drug content with low values of standard deviation established the precision of the proposed methods. Furthermore, the results, expressed as percentage of drug related to label claim, are shown in Table IV. Moreover, the same product batches were analyzed by an HPLC method (Cazedey et al., 2011) and a Student's $t$-test was applied. The Student's $t$-values did not exceed the tabulated value (for five degrees of freedom) indicating no significant difference between the methods. In addition, the two developed methods were used to evaluate the dissolution behavior of orbifloxacin tablets. In both methods, the drug could be assayed and the methods were compared. Again, no statistical difference was found to the HPLC and UV spectrophotometric methods (Table IV).

\section{CONCLUSION}

An UV spectrophotometric method was developed, validated and applied for the determination of orbifloxacin in pharmaceutical dosage form and dissolution tests. The developed method was validated as per ICH guidelines and was found to be accurate, precise, linear, reproducible, robust and selective. No interference from any components of pharmaceutical dosage form was observed. Furthermore, the method did not present any statistically significant difference as compared to the HPLC method.

\section{ACKNOWLEDGEMENT}

This work was supported by PACD-FCFAr-UNESP (Araraquara, Brazil), FAPESP (São Paulo, Brazil) and CNPq (Brasília, Brazil).

\section{RERERENCES}

ABD EL-ATY, A.M.; CHOI, J.-H.; KO, M.-W.; KHAY, S.; GOUDAH, A.; SHIN, H.-C.; KIM, J.-S., CHANG, B.-J.; LEE, C.-H.; SHIM, J.-H. Approaches for application of sub and supercritical fluid extraction for quantification of orbifloxacin from plasma and milk: application to disposition kinetics. Anal. Chim. Acta, v.631, p.108-115, 2009.

ASSOCIATION of Official Analytical Chemists. AOAC. Official methods of analysis of AOAC international. 17ed. Gaithersburg: AOAC International, 2002. v.1, p.20.

BOERLIN, P.; WISSING, A.; AARESTRUP, F.M.; FREY, J.; NICOLET, J. Antimicrobial growth promoter ban and resistance to macrolides and vancomycin in enterococci from pigs. J. Clin. Microbiol., v.39, p.4193-4195, 2001.

BONFILIO, R.; CAZEDEY, E.C.L.; ARAÚJO, M.B.; SALGADO, H.R.N. Analytical validation of quantitative high performance liquid chromatographic methods in pharmaceutical analysis: a practical approach. Crit. Rev. Anal. Chem., v.42, p.87-100, 2012.

BRITISH Pharmacopoeia. London: Her Majesty's Stationery Office, 2011. v.1, p.88-90.

CAZEDEY, E.C.L.; OTHMAN, A.; GARG, S.; SALGADO, H.R.N. A validated stability-indicating LC method for orbifloxacin in the presence of degradation products. Curr. Pharm. Anal., v.7, p.176-181, 2011. 
CAZEDEY, E.C.L.; SALGADO, H.R.N. Development and validation of a microbiological agar assay for determination of orbifloxacin in pharmaceutical preparations. Pharmaceutics, v.3, p.572-581, 2011.

CHO, H.J.; YI, H.; CHO, S.M.; LEE, D.G.; CHO, K.; ABDEL-ATY, A.M.; SHIM, J.H.; LEE, S.H.; JEONG, J.Y.; SHIN, H.C. Single-step extraction followed by LC for determination of (fluoro)quinolone drug residues in muscle, eggs, and milk. J. Sep. Sci., v.33, p.1034-1043, 2010.

CHONAN, T.; FUJIMOTO, T.; INOUE, M.; TAZAWA, T.; OGAWA, H. Multiresidue determination of quinolones in animal and fishery products by HPLC. Shokuhin Eiseiqaku Zasshi, v.49, p.244-248, 2008.

DAVIS, J.L.; PAPICH, M.G.; WEINGARTEN, A. The pharmacokinetics of orbifloxacin in the horse following oral and intravenous administration. J. Vet. Pharmacol. Ther., v.29, p.191-197, 2006.

DIPERSIO, J.R.; JONES, R.N.; BARRETT, T.; DOERN, G.V.; PFALLER, M.A. Fluoroquinolone-resistant Moraxella catarrhalis in a patient with pneumonia: report from the SENTRY. Diagn. Microbiol. Infect. Dis., v.32, p.131-135, 1998.

ELIAS, G.; LEE, J.-S.; HWANG, M.-H.; PARK, Y.-S.; CHO, K.-H.; KIM, Y.-H.; PARK, S.-C. Pharmacokinetics and pharmacokinetic/pharmacodynamic integration of orbifloxacin in Korean Hanwoo cattle. J. Vet. Pharmacol. Ther, v.32, p.219-228, 2009.

EMBORG, H.D.; ANDERSEN, J.S.; SEYFARTH, A.M.; WEGENER, H.C. Relations between the consumption of antimicrobial growth promoters and the occurrence of resistance among Enterococcus faecium isolated from broilers. Epidemiol. Infect., v.32, p.95-105, 2004.

FUJITA, M.; TAMURA, W.; TOZAWA, T.; KOMETANI, T. Application of simultaneous determination method of residual veterinary drugs to processed foods. Shokuhin Eiseiqaku Zasshi, v.49, p.416-421, 2008.

GANIÈRE, J.P.; MÉDAILlE, C.; ETORÉ, F. In vitro antimicrobial activity of orbifloxacin against Staphylococcus intermedius isolates from canine skin and ear infections. Res. Vet. Sci., v.77, p.67-71, 2007.
GARCÍA, M.A.; SOLANS, C.; ARAMAYONA, J.J.; RUEDA, S.; BREGANTE, M.A. Determination of orbifloxacin in rabbit plasma by high-performance liquid chromatography with fluorescence detection. J. Chromatogr. Sci., v.37, p.199-202, 1999.

GEBRU, E.; LEE, J.-S.; CHANG, Z.-Q.; HWANG, M.-H.; CHENG, H.; PARK, S.-C. Integration of pharmacokinetic and pharmacodynamic indices of orbifloxacin in beagle dogs after a single intravenous and intramuscular administration. Antimicrob. Agents Chemother, v.53. p.3024-3029, 2009.

GOMES, G.C.; SALGADO, H.R.N. Spectrophotometric determination of lomefloxacin tablets. Acta Farmacéutica Bonaerense, v.24, p.406-408, 2005.

GRAVE, K.; TANEM, H. Compliance with short-term oral antibacterial drug treatment in dogs. J. Small. Anim. Pract., v.40, p.158-162, 1999.

HAINES, G.R.; BROWN, M.P.; GRONWALL, R.R.; MERRITT, K.A.; BALTZLEY, L.K. Pharmacokinetics of orbifloxacin and its concentration in body fluids and in endometrial tissues of mares. Can. J. Vet. Res., v.65, p.181$187,2001$.

HUNG, S.-W.; SHIH, C.-W.; CHEN, B.-R.; TU, C.-Y.; LING, Y.-F.; TSOU, L.-T.; HO, S.-P.; WANG, W.-S. A new detection technique for fluoroquinolone-conjugated proteins by high performance liquid chromatography with UV/ fluorescence detectors. J. Food. Drug Anal., v.15, p.71-74, 2007.

INTERNATIONAL Conference on Harmonization. ICH. Validation of analytical procedures: text and methodology Q2(R1). Geneva: IFPMA, 2005. Available at: http:// www.ich.org/fileadmin/Public_Web_Site/ICH_Products/ Guidelines/Quality/Q2_R1/Step4/Q2_R1_Guideline.pdf. Accessed on: May 2014.

JOHNSTON, L.; MACKAY, L.; CROFT, M. Determination of quinolones and fluoroquinolones in fish tissue and seafood by high-performance liquid chromatography with electrospray ionisation tandem mass spectrometric detection. J. Chromatogr. A, v.982, p.97-109, 2002.

KAJITA, H.; HATAKEYAMA, E. Simultaneous determination of residual veterinary drugs in livestock products and fish by liquid chromatography with tandem mass spectrometry. Shokuhin Eiseiqaku Zasshi, v.49, p.381-389, 2008. 
KANTIANI, K.; FARRÉ, M.; BARCELO, D. Rapid residue analysis of fluoroquinolones in raw bovine milk by online solid phase extraction followed by liquid chromatography coupled to tandem mass spectrometry. J. Chromatogr. A, v.1218, p.9019-9027, 2011.

KAY-MUGFORD, P.A.; WEINGARTEN, A.J.; NGOH, M.; ZOLYNAS, R.; WHITE, A.; KATZ, T.; SIMMONS, R.; VARMA, K.J. Determination of plasma and skin concentrations of orbifloxacin in dogs with clinically normal skin and dogs with pyoderma. Vet. Ther., v.3, p.402-408, 2002.

LI, Y.L.; HAO, X.L.; JI, B.Q.; XU, C.L.; CHEN, W.; SHEN, C.Y.; DING, T. Rapid determination of 19 quinolone residues in spiked fish and pig muscle by high-performance liquid chromatography (HPLC) tandem mass spectrometry. Food Addit. Contam., v.26, p.306-313, 2009.

LLORENT-MARTÍNEZ, E.J.; ORTEGA-BARRALES, P.; MOLINA-DÍAZ, A.; RUIZ-MEDINA, A. Implementation of terbium-sensitized luminescence in sequential-injection analysis for automatic analysis of orbifloxacin. Anal. Bioanal. Chem., v.392, p.1397-1403, 2008.

SALGADO, H.R.N.; OLIVEIRA, C.L.C.G. Development and validation of a UV spectrophotometric method for determination of gatifloxacin in tablets. Pharmazie, v.60, p.263-264, 2005.

MARÍN, P.; ESCUDERO, E.; FERNÁNDEZ-VARÓN, E.; CÁRCELES, C.M. Pharmacokinetics and milk penetration of orbifloxacin after intravenous, subcutaneous, and intramuscular administration to lactating goats. J. Dairy Sci., v.90, p.4219-4225, 2007.

MARÍN, P.; FERNÁNDEZ-VARÓN, E.; ESCUDERO, E.; VANCRAEYNEST, D.; CÁRCELES, C.M.P. Pharmacokinetic-pharmacodynamic integration of orbifloxacin in rabbits after intravenous, subcutaneous, and intramuscular administration. J. Vet. Pharmacol. Ther, v.31, p.77-82, 2008.

SALGADO, H.R.N.; OLIVEIRA, C.L.C.G. Development and validation of an UV spectrophotometric method for determination of gatifloxacin in tablets. Pharmazie, v.60, p.263-264, 2005.

MARONA, H.R.N.; SCHAPOVAL, E.E.S. Spectrophotometric determination of sparfloxacin in tablets. J. Antimicrob. Chemother., v.44, p.136-137, 1999.
MARTINEZ, M.; MCDERMOTT, P.; WALKER, R. Pharmacology of the fluoroquinolones: a perspective for the use in domestic animals. Vet. J., v.172, p.10-28, 2006.

MATSUMOTO, S.; KITADAI, N.; NAKATA, K.; KATAE, H. Combined in vitro effects of orbifloxacin and fosfomycin on S. dublin and S. typhimurium isolated from calves. J. Jpn. Vet. Med. Assoc., v.53, p.1-6, 1999a.

MATSUMOTO, S.; NAKAI, M.; YOSHIDA, M.; KATAE, H. A study of metabolites isolated from urine samples of pigs and calves administered orbifloxacin. J. Vet. Pharmacol. Ther., v.22, p.286-289. 1999b.

MATSUMOTO, S.; NAKAI, M.; YOSHIDA, M.; KATAE, H. Absorption, distribution and excretion of orbifloxacin in swine and calves. J. Jpn. Vet. Med. Assoc., v.51, p.13-18, 1998a.

MATSUMOTO, S.; TAKAHASHI, M.; KITADAI, N.; KATAE, $\mathrm{H}$. A study of metabolites isolated from the urine samples of cats and dogs administered orbifloxacin. J. Vet. Med. Sci., v.60, p.1259-1261, 1998b.

MCKAY, L.; ROSE CRYSTAL, D.S.; MATOUSEK, J.L.; SCHMETIZEL, L.S.; GIBSON, N.M.; GASKIN, J.M. Antimicrobial testing of selected fluoroquinolones against Pseudomonas aeruginosa isolated from canine otitis. J. Am. Anim. Hosp. Assoc., v.43, p.307-312, 2007.

MORIMURA, T.; KOHNO, K.; NOBUHARA, Y.; MATSUKURA, H. Photoreaction and active oxygen generation by photosensitization of a new antibacterial fluoroquinolone derivative, orbifloxacin, in the presence of chloride ion. Chem. Pharm. Bull., v.45, p.1828-1832, 1997.

MORIMURA, T.; NOBUHARA, Y.; MATSUKURA, $\mathrm{H}$. Photodegradation products of a new antibacterial fluoroquinolone derivative, orbifloxacin, in aqueous solution. Chem. Pharm. Bull., v.45, p.373-377, 1997.

MORIMURA, T.; OHNO, T.; MATSUKURA, H.; NOBUHARA, Y. Degradation kinetics of the new antibacterial fluoroquinolone derivative, orbifloxacin, in aqueous solution. Chem. Pharm. Bull., v.43, p.1052-1054, 1995a.

MORIMURA, T.; OHNO, T.; MATSUKURA, H.; NOBUHARA, Y. Photodegradation kinetics of the new antibacterial fluoroquinolone derivative, orbifloxacin, in aqueous solution. Chem. Pharm. Bull., v.43, p.1000-1004, 1995 b. 
NAKAMURA, S. Veterinary use of the new quinolones in Japan. Drugs, v.49, p.152-158, 1995.

RANTALA, M.; HOLSO, K.; LILLAS, A.; HUOVINEN, P.; KAARTINEN, L. Survey of condition-based prescribing of antimicrobial drugs for dogs at a veterinary teaching hospital. Vet. Rec., v.155, p.259-262, 2004.

SAITO, M.; KOZUTSUMI, D.; KAWASAKI, M.; KANBASHI, M.; NAKAMURA, R.; SATO, Y.; ENDO, M. Multiresidue method for pesticides and veterinary drugs in bovine milk using GC/MS and LC/MS/MS. Shokuhin Eiseiqaku Zasshi, v.49, p.228-238, 2008.

SANTOKE, H.; SONG, W.; COOPER, W.J.; GREAVES, J.; MILLER, G.E. Free-radical-induced oxidative and reductive degradation of fluoroquinolone pharmaceuticals: Kinetic studies and degradation mechanism. J. Phys. Chem. A., v.113, p.7846-7851, 2009.

SCHNEIDER, M.J.; DONOGHUE, D.J. Multiresidue analysis of fluoroquinolone antibiotics in chicken tissue using liquid chromatography-fluorescence-multiple mass spectrometry. J. Chromatogr. B Analyt. Technol. Biomed. Life Sci.,v.780, p.83-92, 2002.

SCHNEIDER, M.J.; DONOGHUE, D.J. Multiresidue determination of fluoroquinolone antibiotics in eggs using liquid chromatography-fluorescence-mass spectrometry. Anal. Chim. Acta, v.483, p.39-49, 2003.

SCHNEIDER, M.J.; REYES-HERRERA, I.; DONOGHUE, D.J. Evaluation of serum as a potential matrix for multiresidue determination of fluoroquinolone antibiotics in chicken using liquid chromatography-fluorescence-mass spectrometry. J. AOAC Int., v.90, p.1716-1723, 2007.
SCHNEIDER, M.J.; VAZQUEZ-MORENO, L.; BERMUDEZALMADA, M.C.; GUARDADO, R.B.; ORTEGANIEBLAS, M. Multiresidue determination of fluoroquinolones in shrimp by liquid chromatographyfluorescence-mass spectrometry. J. AOAC Int., v.88, p.11601166, 2005.

SCOTT, D.W.; PETERS, J.; MILLER JR, W.H. Efficacy of orbifloxacin tablets for the treatment of superficial and deep pyoderma due to Staphylococcus intermedius infection in dogs. Can. Vet. J., v.47, p.999-1002, 2006.

TANG, Y.Y.; LU, H.F.; LIN, H.Y.; SHIH, Y.C.; HWANG, D.F. Multiclass analysis of 23 veterinary drugs in milk by ultraperformance liquid chromatography-electrospray tandem mass spectrometry. J. Chromatogr. B. Analyt. Technol. Biomed. Life Sci., v.881-882, p.12-19, 2012.

UNITED STATES PHARMACOPEIA. 34ed. USP 34. Rockville: The United States Pharmacopeial Convention, 2011. p.3732-3734.

YAMADA, R.; KOZONO, M.; OHMORI, T.; MORIMATSU, F.; KITAYAMA, M. Simultaneous determination of residual veterinary drugs in bovine, porcine, and chicken muscle using liquid chromatography coupled with electrospray ionization tandem spectrometry. Biosci. Biotechnol. Biochem., v.70, p.54-65, 2006.

YU, H.; TAO, Y.; CHEN, D.; PAN, Y.; LIU, Z.; WANG, Y.; HUANG, L.; DAI, M.; PENG, D.; WANG, X.; YUAN, Z. Simultaneous determination of fluoroquinolones in foods of animal origin by a high performance liquid chromatography and a liquid chromatography tandem mass spectrometry with accelerated solvent extraction. J. Chromatogr. B. Analyt. Technol. Biomed Life Sci., v.885-886, p.150-159, 2012. 
